\title{
Effect of immunization of rams against bovine inhibin $\alpha 1-26$ on semen characteristics, scrotal size, FSH, LH and testosterone concentrations
}

\author{
R. M. McKeown ${ }^{1}$, D. O'Callaghan ${ }^{2}$, J. F. Roche ${ }^{2}$ and M. P. Boland ${ }^{1 *}$ \\ ${ }^{1}$ Faculty of Agriculture, University College Dublin, Belfield, Dublin 4, Ireland; and ${ }^{2}$ Faculty of Veterinary \\ Medicine, University College Dublin, Ballsbridge, Dublin 4, Ireland
}

\begin{abstract}
The effects of inhibin immunization on inhibin antibody titres, semen characteristics, scrotal size, fertility, FSH, LH and testosterone concentrations were determined by immunizing adult rams against bovine inhibin $\alpha 1-26-G l y-T y r$ conjugated to human serum albumin $(n=16)$ in non-ulcerative Freund's adjuvant and DEAE:dextran (1:1) or adjuvant alone $(n=16)$ on days 0 (29 June), 30,60,191, 303 and 394. Blood samples were collected and bovine inhibin $\alpha 1-26-G l y-T y r$ antibody titres and serum testosterone concentrations were determined. Each month, between days 174 and 417, semen was collected every 30 min to a maximum of 15 ejaculates over $7 \mathrm{~h}$ and scrotal circumference was measured. Ram fertility was recorded during natural service. $\mathrm{FSH}, \mathrm{LH}$ and testosterone concentrations and GnRH-induced FSH and LH release were measured in a subgroup of immunized $(n=5)$ and control $(n=5)$ rams at frequent intervals. Antibody titres were variable among immunized rams $\left(0-46 \%{ }^{12.5}\right.$ I-labelled bovine inhibin $\alpha 1-26-$ Gly-Tyr at 1:1600 serum dilution) but mean titres were consistently higher than in control rams $(P \leq 0.001)$. Immunization did not alter the semen volume, output or quality of spermatozoa or ram fertility, but increased the mean scrotal circumference $(37.6 \pm 0.8 \mathrm{~cm}$ versus $34.4 \pm 0.7 \mathrm{~cm}, P<0.001)$. Mean FSH concentrations were higher in immunized rams during two intensive blood sampling periods (in June and August) $\left(5.8 \pm 0.7 \mathrm{ng} \mathrm{ml}^{-1}\right.$ versus $3.0 \pm 0.3 \mathrm{ng} \mathrm{ml}^{-1}, P<0.001$ in June; and $4.8 \pm 0.9 \mathrm{ng} \mathrm{ml}^{-1}$ versus $2.0 \pm 0.3 \mathrm{ng} \mathrm{ml}^{-1}, P<0.02$ in August), and were correlated with antibody titres $\left(r^{2}=0.3, P<0.05\right.$ in June; and $r^{2}=0.8, P<0.001$ in August). Discrete FSH pulses were not detected. Immunization did not alter mean or basal testosterone or LH concentrations, or LH pulse frequency; LH pulse amplitude was increased (1.6 $\pm 0.2 \mathrm{ng}$ $\mathrm{ml}^{-1}$ versus $\left.0.8 \pm 0.2 \mathrm{ng} \mathrm{ml}^{-1}, P<0.02\right)$ and was correlated with antibody titres $\left(r^{2}=0.6\right.$, $P<0.01)$. Immunization enhanced GnRH-induced FSH $(P<0.05)$ but not LH release. In conclusion, immunization of adult rams against bovine inhibin $\alpha 1-26$ Gly-Tyr increased scrotal circumference, mean FSH concentrations and LH pulse amplitude, without altering semen characteristics, fertility, mean LH concentrations, LH pulse frequency or mean testosterone concentrations.
\end{abstract}

\section{Introduction}

Although the roles of gonadotrophins and androgens in the initiation, regulation and maintenance of spermatogenesis are currently being elucidated, their definitive roles are still unclear. The differentiation of $A_{0}$ to $A_{I}$ spermatogonia appears to be sensitive to LH, while multiplication from intermediate to $B_{2}$ spermatogonia, and therefore the rate of spermatogenesis, is dependent on $\mathrm{FSH}$; meiotic divisions and spermiogenesis are maintained by testosterone (Courot et al., 1979; Kilgour et al, 1993). Although testosterone alone can qualitatively support spermatogenesis in the rat (Boccabella, 1963), gonadotrophins

*Correspondence

Revised manuscript received 28 November 1996. are also required for quantitative support of spermatogenesis (Barlett et al., 1989; Awonyi et al., 1990; Kilgour et al., 1993). Hormonal profiles following unilateral castration indicate that FSH is a key determinant of the rate of spermatogenesis (Walton et al., 1978; Waites et al., 1983; Schanbacher, 1988). Furthermore, FSH plays a primary role in determining testicular size in rams (Lincoln and McNeilly, 1989; Lincoln et al., 1990), while scrotal circumference is highly correlated with testicular mass and sperm production (Willett and Ohms, 1957; Foote, 1978; Coulter, 1980; Cameron et al., 1984a, b).

Inhibins are glycoprotein hormones consisting of two dissimilar subunits, $\alpha$ and $\beta$, joined by disulfide bonds, which preferentially inhibit the production or secretion of FSH or both processes (Burger and Igarashi, 1988). Inhibins occur in various forms with different molecular masses and bioactivity; 


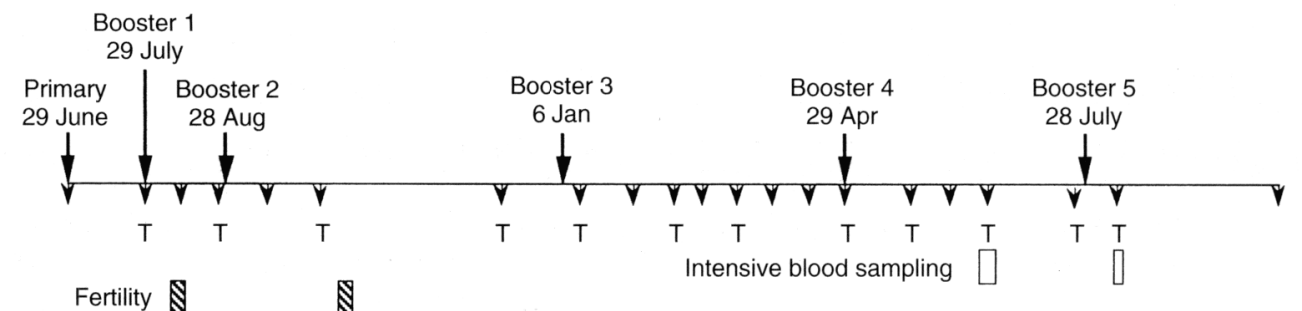

\begin{tabular}{|c|c|c|c|c|c|c|c|c|c|c|c|c|c|c|c|c|}
\hline June & July & Aug & Sep & Oct & Nov & $\mathrm{Dec}$ & Jan & Feb & Mar & Apr & May & June & July & Aug & Sep & Oct \\
\hline & & & & & & & 191 & & & & & & & & & 470 \\
\hline
\end{tabular}

Fig. 1. Experimental protocol. Rams $(n=16)$ received a primary immunization against bovine inhibin a1-26-Gly-Tyr (bINH) conjugated to human serum albumin on day 0 (29 June) and boosters on days 30, 60, 191, 303 and 394. Control rams $(n=16)$ received adjuvant alone on the same days. Blood samples were collected throughout the experimental period for determination of bINH antibody titres ( $\boldsymbol{V}$ ) and serum testosterone concentrations (T). Semen ( $\square$ ) was collected each month between day 174 (December) and day 417 (August) and scrotal circumference ( $\boldsymbol{\square}$ ) was measured between day 196 (January) and day 417 (August). Rams were mated $(\nabla)$ in August (day 44) and October (day 109). Intensive blood samples were collected ( $\square$ ) in June (days 358-360) for FSH determination and in August (day 407) for FSH, LH and testosterone determination.

the principal bioactive form in the circulation is $30-32 \mathrm{kDa}$ inhibin (de Kretser and Robertson, 1989; Tilbrook et al., 1992). FSH stimulates the secretion of inhibins from Sertoli cells in vitro (Le Gac and de Kretser, 1982; Verhoeven and Franchimont, 1983; Ultee van-Gessel et al., 1986; Bicsak et al., 1987; Gonzales et al., 1988) and in vivo (Au et al., 1984) by a cAMP-dependent mechanism (Bicsak et al., 1987). Inhibins, in turn, suppress FSH release from the anterior pituitary in vitro (Muttukrishna and Knight, 1990) and in vivo (Tilbrook et al., 1993a, b); this interaction is consistent with a closed-loop, endocrine feedback system. In addition to this systemic role, there is increasing evidence that inhibins inhibit spermatogonial development in a paracrine manner (van-Dissel-Emiliani et al., 1989; Hakovitra et al., 1993) and modulate LH-stimulated testosterone secretion (Hsueh et al., 1987). Therefore, it can be hypothesized that inhibins play a substantial role in regulating testicular function and the rate of spermatogenesis through selective suppression of the concentration of FSH in peripheral blood.

However, there are conflicting results from experiments in which males have been immunized against different inhibin immunogens. Active immunization against inhibin-enriched follicular fluid or inhibins themselves has been reported to increase the daily sperm output in the urine of ram lambs (Al-Obaidi et al., 1987) and the testicular sperm density in bulls (Martin et al., 1991; Schanbacher, 1991) but to have no significant effect on the epididymal sperm reserves of adult rams (Voglmayr et al, 1990) or the daily sperm output of bulls (Schanbacher, 1991). Testis size is increased (Al-Obaidi et al, 1987) or unaffected (Martin et al., 1991; Schanbacher, 1991), while $\mathrm{LH}$ and testosterone concentrations have either been altered (Voglmayr et al., 1990; Martin et al., 1991) or unchanged (Al-Obaidi et al., 1987; Schanbacher, 1991) by inhibin immunization. In females, immunization against synthetic peptides from the carboxy-terminal region of the inhibin a subunit has successfully increased ovulation rate in rats
(Rivier and Vale, 1989), heifers (Morris et al., 1993, Scanlon et al., 1993) and ewes (Wrathall et al., 1990; Boland et al., 1994). Although there are sex-related differences with respect to the functions of inhibins (van Dijk et al., 1986), collectively these data augur well for the use of inhibin immunization to increase the rate of sperm production in males.

We hypothesized that inhibins have a role in the regulation of sperm production and in the determination of testis size by their ability to suppress circulating FSH concentrations. This hypothesis was tested by actively immunizing adult rams against the $\alpha 1-26$ subunit of bovine inhibin. The main objectives of this experiment were to determine the antibody titre response, to monitor changes in scrotal circumference, daily sperm output and sperm quality over an extended period, and to observe the fertility of immunized rams. The secondary objectives of this study were to examine the effects of inhibin immunization on detailed FSH, LH and testosterone blood profiles, and on GnRH-induced FSH and LH release.

\section{Materials and Methods}

\section{Animals and treatments}

Adult rams ( $n=32$, comprising Suffolk, Texel, Blue-faced Leicester and Dorset Horn) were paired on the basis of breed, weight and age, and randomly allocated within pairs to one of two treatment groups. One group of rams $(n=16)$ was immunized against bovine inhibin $\alpha 1-26-\mathrm{Gly}-\mathrm{Tyr}(\mathrm{bINH})$ conjugated to human serum albumin (HSA) by the gluteraldehyde method (Reichlin, 1980). The ratio of weight of bINH:HSA after conjugation was approximately $1: 1$. The rams received a primary immunization (on 29 June, day 0; Fig. 1) consisting of $0.33 \mathrm{mg}$ bINH-HSA conjugate emulsified separately in $1.25 \mathrm{ml}$ DEAE-dextran (D1162; Sigma-Aldrich Co. Ltd, Poole) and $1.235 \mathrm{ml}$ non-ulcerative Freund's adjuvant (NUFA, F010; 
Guildhay Antisera Ltd, Guildford), with $0.1 \mathrm{ml}$ Corynebacterium paroum vaccine (Wellcome Ireland Ltd, Dublin) in the DEAEdextran emulsion. Rams received identical booster injections on days $30,60,191,303,394$ but without $C$. parvum added. All immunizations were given subcutaneously in two sites behind the shoulder. Control rams $(n=16)$ received $625 \mu$ DEAEdextran and $625 \mu$ l NUFA emulsified in a single injection.

\section{Scrotal circumference}

Measurements of scrotal circumferences were carried out monthly between day 196 (January) and day 417 (August) using a flexible measuring tape to measure the widest point of the scrotum with the ram standing. Body weight and body condition score (Russell et al., 1969) were recorded on the same day. All measurements were performed by the same operator.

\section{Semen collection and evaluation}

Semen was collected from each ram using an artificial vagina once per month between day 174 (December) and day 417 (August) at $30 \mathrm{~min}$ intervals over $7 \mathrm{~h}$, to a maximum of 15 ejaculates or until rams were sexually exhausted. Rams that failed to ejaculate within $5 \mathrm{~min}$ of being introduced to the ewe were excluded until the following collection time. Ejaculate volume, sperm concentration and wave motion were evaluated for each ejaculate immediately following collection according to recognized procedures (Evans and Maxwell, 1987). Ejaculate volume was measured to the nearest $0.1 \mathrm{ml}$ using a $2 \mathrm{ml}$ syringe. The concentration of spermatozoa was measured in a colorimeter previously calibrated using a haemocytometer (checked against standard solutions on each day of collection), and the output of spermatozoa for each ejaculate was estimated as the product of ejaculate volume and sperm concentration. The wave motion of undiluted semen was assessed using a heated stage $\left(37^{\circ} \mathrm{C}\right)$ under a microscope at a magnification of $\times 100$, scored on a scale of $0-5$. Spermatozoa were stained by mixing $0.1 \mathrm{ml}$ semen with $0.7 \mathrm{ml}$ nigrosin-eosin solution (10:1.6\% w/v; Hancock, 1951) in a $6 \mathrm{~mm} \times 75 \mathrm{~mm}$ polystyrene tube and incubating them in a water bath for $3 \mathrm{~min}$ at $30^{\circ} \mathrm{C}$. Smears were made and air-dried on prewarmed slides $\left(30^{\circ} \mathrm{C}\right)$ from the second, eighth, and fourteenth ejaculates. The smears were examined under a microscope at a magnification of $\times 400$ as dry preparations. A total of 100 spermatozoa from five separate fields were counted on each slide, and the percentage of dead spermatozoa and the incidence of primary and secondary abnormalities were recorded.

\section{Fertility}

Four groups of rams, (a) immunized Suffolk $(n=4)$, (b) immunized Texel $(n=8)$, (c) control Suffolk $(n=4)$ and (d) control Texel $(n=8)$, were mated with separate groups of synchronized crossbred ewes during the first breeding season after immunization (on 12 August, day 44, and 16 October, day 109). Immunized and control rams were mated with a total of 212 and 213 ewes, respectively. The proportion of ewes pregnant and lambs per ewe to first service were calculated.

\section{Blood samples for inhibin antibody titres and hormone} concentrations

Blood samples were collected by jugular venepuncture at 14-30 day intervais from day 0 until the end of the experiment (day 470; Fig. 1) to determine bINH antibody titres. Blood samples were not collected in November as the rams were breeding and therefore unavailable. Titres were determined as described by Martin et al. (1991). bINH radiolabelled with ${ }^{125}$ I was incubated with $200 \mu \mathrm{l}$ serum diluted 1:100, 1:400, 1:1600 and 1:6400. The percentage of radiolabelled bINH bound to serum diluted 1:1600 (on the linear portion of dilution curve) was used in the presentation of bINH antibody titres. Serum testosterone concentrations were measured by radioimmunoassay once per month except during November. FSH concentrations were determined from blood samples collected every $3 \mathrm{~h}$ for $12 \mathrm{~h}$ on 3 consecutive days in June (days 358-360).

FSH and LH concentrations were measured in a subgroup of immunized rams $(n=5)$ selected on the basis of titre response in December (day 171) and control rams $(n=5)$ selected at random, to determine whether active immunization against inhibins alters blood hormone profiles. Rams were housed individually and fitted with an indwelling jugular cannula $24 \mathrm{~h}$ before blood sampling began. Blood samples were collected every $12 \mathrm{~min}$ for $12 \mathrm{~h}$ (on 10 August, day 407, 13 days after booster 5). Testosterone concentrations were subsequently measured in the same sera every $12 \mathrm{~min}$ for a specific $2-4 \mathrm{~h}$ period selected to span two LH pulses in each ram.

A single injection of the GnRH analogue Buserelin (PL0086/ 4125; Hoechst AG, Frankfurt) was given intravenously (40 ng $\mathrm{kg}^{-1}$ ) at the end of this $12 \mathrm{~h}$ sampling period, and blood samples were collected every $12 \mathrm{~min}$ for a further $3 \mathrm{~h}$, to establish whether active immunization against inhibins altered GnRH-induced FSH and LH release.

After collection, blood samples were incubated at room temperature for $1 \mathrm{~h}$ and overnight at $4^{\circ} \mathrm{C}$, samples were centrifuged at $700 \mathrm{~g}$ for $20 \mathrm{~min}$, and the serum was then decanted and stored at $-20^{\circ} \mathrm{C}$ until assayed.

Serum FSH concentrations were determined by a radioimmunossay (Crowe et al., 1995) modified for ovine serum (Sweeney, 1995). The interassay coefficients of variation $(n=5)$ for three serum pools of $1.4,3.0$ and $8.1 \mathrm{ng} \mathrm{ml}^{-1}$ were $10.8 \%$, $9.3 \%$ and $7.2 \%$, respectively. The intra-assay coefficients of variation $(n=5)$ for the same serum pools were $9.4 \%, 10.5 \%$ and $9.1 \%$, respectively. The sensitivity of the ovine FSH assay, as defined by $95 \%$ binding, was $0.4 \mathrm{ng} \mathrm{ml}^{-1}$.

Serum $\mathrm{LH}$ concentrations were determined by a radioimmunoassay using the method described by Matteri et al. (1987) and modified for use in sheep (Sweeney, 1995). The interassay coefficients of variation ( $n=5$ ) for three serum pools of $0.4,2.1$ and $4.5 \mathrm{ng} \mathrm{ml}^{-1}$ were $8.6 \%, 6.2 \%$ and $2.9 \%$, respectively. The intra-assay coefficients of variation $(n=5)$ for the same serum pools were $9.5 \%, 6.9 \%$ and $2.4 \%$, respectively. The sensitivity of the ovine LH assay, as defined by $95 \%$ binding, was $0.2 \mathrm{ng} \mathrm{ml}^{-1}$.

Testosterone concentrations were determined by a direct radioimmunoassay described by Schanbacher and D'Occhio (1982), validated by Ronayne et al. (1993) and rechecked for the measurement of testosterone in ovine serum. Briefly, $10 \mu \mathrm{l}$ 
serum was incubated for $24 \mathrm{~h}$ at $4^{\circ} \mathrm{C}$ in $390 \mu \mathrm{l}$ phosphate buffer $(\mathrm{pH} 7.4), 100 \mu \mathrm{l}$ anti-testosterone solution (1:400 000 dilution GDN506; Ronayne et al. (1993) and $100 \mu \mathrm{l}\left[{ }^{[25} \mathrm{I}\right]$ testosterone solution (10000 c.p.m. in $100 \mu \mathrm{l}$; Amersham). A charcoal suspension $(500 \mu \mathrm{l} ; 5 \%(\mathrm{w} / \mathrm{v})$ activated charcoal and $0.5 \%(\mathrm{w} / \mathrm{v})$ dextran) was added to each tube for $5 \mathrm{~min}$ and tubes were centrifuged for $10 \mathrm{~min}$ at $2000 \mathrm{~g}$. The supernatant fluid was decanted into vials and the amount of radioactivity measured in a gamma counter. The standard testosterone used was T1500 (Sigma-Aldrich Co. Ltd). Serum samples from adult rams during the breeding and non-breeding seasons and from ram lambs all produced displacement curves parallel to the standard curve. The recovery rate was $91 \%$ for a sample ( $1 \mathrm{ng} \mathrm{ml}{ }^{-1}$ ) with I ng testosterone $\mathrm{ml}^{-1}$ added, assayed in duplicate. The interassay coefficients of variation $(n=8)$ for three serum pools of $1.0,2.7$ and $4.0 \mathrm{ng} \mathrm{ml}^{-1}$ were $15.9 \%, 9.3 \%$ and $4.9 \%$, respectively. The intra-assay coefficients of variation $(n=8)$ for the same serum pools were $13.4 \%, 10.4 \%$ and $11.1 \%$, respectively. The sensitivity of the testosterone assay, as defined by $95 \%$ binding, was $0.1 \mathrm{ng} \mathrm{ml}^{-1}$.

\section{Statistical analysis}

Unless otherwise stated, all values shown are means \pm SEM. Semen parameters, scrotal circumference and testosterone concentration (monthly samples) were subjected to repeat measures ANOVA. Chi-squared analysis was used to compare the effect of immunization on the proportion of dead and morphologically abnormal spermatozoa with that in control rams. Fertility data were analysed separately to compare the effects of the experiment on different ram breeds and mating dates. As there were no differences between Suffolk and Texel breeds, nor between matings on days 44 and 109, all data were pooled to determine differences between immunized and control rams. The proportion of pregnant ewes was analysed by $\chi^{2}$ analysis and litter size by ANOVA. The parameters of FSH, LH and testosterone hormone profiles were determined by the PC-Pulsar pulse detection algorithm (Merriam and Wachter, 1982). The $G$ parameters used were $G(I)=5.00, G(2)=1.90$, $G(3)=1.80, G(4)=1.30$ and $G(5)=1.20$. Basal concentrations described in this study are equivalent to the 'smoothed mean' values from PC-Pulsar. The amplitude of each hormone pulse was the difference between the peak value and this basal concentration. The assay SD terms for PC-Pulsar were obtained as follows: the SD of replicate standards at seven doses (five replicates per dose for the FSH assay and eight replicates per dose for the $\mathrm{LH}$ and testosterone assays) were calculated. The $\mathrm{SD}$ of each dose was then fitted to the corresponding mean values using least squares regression. This gave constant, linear and quadratic values for each assay for the PC-Pulsar program. Pulse frequency was not determined for testosterone as only one pulse was measured in each ram. GnRH-induced FSH and $\mathrm{LH}$ release were determined as the area under the response curve above basal concentrations (calculated by triangulation). Comparisons between groups on all hormone parameters were made using ANOVA. When a significance level of $P<0.05$ was obtained, the analysis was followed by the PLSD Fisher test and Scheffe F-test. Linear regression analysis was used to examine the degree of correlation between different variables as mentioned in the text.

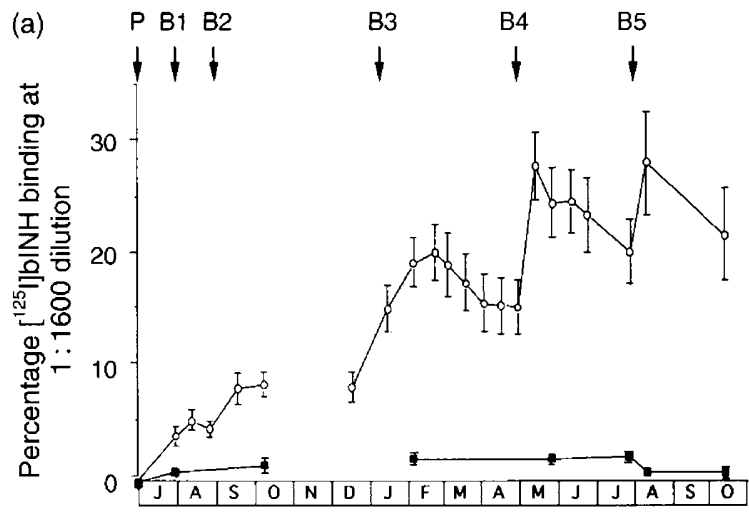

(b)

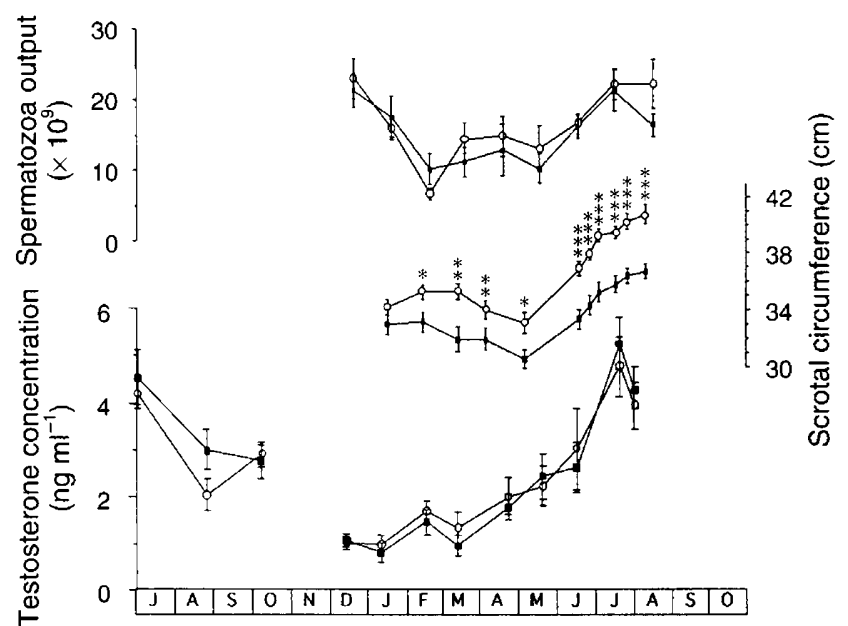

Fig. 2. (a) Mean ( \pm SEM) antibody titre (\% radioiodinated bovine inhibin $\alpha 1-26-G l y-T y r\left(\left[I^{i 25}\right] \mathrm{bINH}\right)$ bound at 1:1600 of dilution) of immunized $(n=16 ; \bigcirc)$ and control $(n=16 ; \mathbf{\square})$ rams. Primary immunization (P) was given on 29 June (day 0), booster 1 (BI) on day 30 , booster 2 (B2) on day 60 , booster 3 (B3) on day 191, booster 4 (B4) on day 303, and booster 5 (B5) on day 394. (b) Output of spermatozoa, scrotal circumference and serum testosterone concentrations of immunized $(n=16 ; 0)$ and control $(n=16 ; \boldsymbol{\square})$ rams. Values are means ( \pm SEM) and asterisks above points indicate whether means for immunized rams are significantly different $\left({ }^{*} P<0.05\right.$, $\left.{ }^{* *} P<0.01,{ }^{* * *} P<0.001\right)$ from controls.

\section{Results}

\section{Inhibin antibody titres}

Antibody titres were detected in bINH-immunized rams 30 days after the primary immunization and these became larger following each booster (Fig. 2a). However, titres were highly variable among immunized rams $\left(0-46 \%{ }^{125}\right.$ I-labelled bINH at 1:1600 dilution): four of the 16 rams had greater than $40 \%$ maximal binding; six had 30-40\%; three had $20-30 \%$; and three had less than $20 \%$ throughout the experiment. Titres remained high from December (day 174) until October (day 478) during the main experimental period. Mean bINH antibody titres were consistently higher in immunized compared with control rams $(P \leq 0.001)$. 
Table 1. The effects of immunization of adult rams against bovine inhibin a1-26-Gly-Tyr on semen characteristics between days 174 (December) and 417 (August) and on scrotal circumference between days 196 (January) and 417 (August); values are totals from all ejaculates or means ( \pm SEM) over a 9-month experimental period

\begin{tabular}{lcc}
\hline & Control & Immunized \\
\hline Number of rams & 16 & 16 \\
Total number of ejaculates & 1076 & 1316 \\
Mean semen volume per ejaculate $(\mathrm{ml})$ & $0.54 \pm 0.04^{\mathrm{a}}$ & $0.55 \pm 0.04^{\mathrm{a}}$ \\
Mean sperm output per ejaculate $\left(\times 10^{9}\right)$ & $1.54 \pm 0.15^{\mathrm{a}}$ & $1.61 \pm 0.11^{\mathrm{a}}$ \\
Mean sperm concentration (number per $\left.\mathrm{ml} \times 10^{9}\right)$ & $2.82 \pm 0.07^{\mathrm{a}}$ & $2.98 \pm 0.06^{\mathrm{a}}$ \\
Mean sperm motility (scale 0-5) & $2.77 \pm 0.09^{\mathrm{a}}$ & $2.90 \pm 0.05^{\mathrm{a}}$ \\
Dead spermatozoa (\%) & $10.34 \pm 1.00^{\mathrm{a}}$ & $10.52 \pm 1.02^{\mathrm{a}}$ \\
Morphologically abnormal spermatozoa (\%) & $6.00 \pm 0.50^{\mathrm{a}}$ & $6.16 \pm 0.48^{\mathrm{a}}$ \\
$\quad$ Primary abnormalities (\%) & $1.72 \pm 0.26^{\mathrm{a}}$ & $1.94 \pm 0.22^{\mathrm{a}}$ \\
Secondary abnormalities (\%) & $4.38 \pm 0.31^{\mathrm{a}}$ & $3.71 \pm 0.56^{\mathrm{a}}$ \\
Scrotal circumference (cm) & $34.36 \pm 0.68^{\mathrm{a}}$ & $37.59 \pm 0.77^{\mathrm{b}}$ \\
\hline
\end{tabular}

a.b Values in a row with different superscripts are significantly different $(P<0.001)$

\section{Scrotal circumference and seasonal testosterone changes}

Immunized rams had a greater scrotal circumference compared with controls (Fig. 2b) throughout the measurement period $(P<0.05)$ except during January $(P=0.18)$. From June to August the difference between the scrotal circumference of immunized and control rams was highly significant $(P<0.001)$. However, scrotal circumference was not correlated with antibody titre $(P>0.05)$.

Changes in serum testosterone concentrations showed a distinct seasonal pattern in rams assigned to both treatment groups (Fig. 2b). Testosterone decreased from the concentration recorded in July to a nadir in January, and increased from March to a peak in July before declining again. Mean testosterone concentrations were not different in immunized rams compared with controls $(P>0.05)$, and neither were they correlated with antibody titre $(P>0.05)$.

\section{Semen characteristics}

With the exception of transient effects, immunization did not alter semen volume, spermatozoa output, spermatozoa concentration or spermatozoa quality over the 9 month collection period (Table 1). Immunized rams had a lower total semen volume in February $(2.1 \pm 0.3 \mathrm{ml}$ versus $3.4 \pm 0.6 \mathrm{ml}, P<0.05)$ but a higher concentration of spermatozoa in August ( $2.5 \pm 0.1$ $\times 10^{9}$ spermatozoa $\mathrm{ml}^{-1}$ versus $2.2 \pm 0.06 \times 10^{9}$ spermatozoa $\left.\mathrm{ml}^{-1}, P<0.001\right)$ compared with controls. There was a seasonal change in semen volume and output of spermatozoa (Fig. 2b) similar to the cycle in scrotal circumference.

\section{Fertility}

There was no difference in the proportion of ewes pregnant to first service $(75.0 \%$ versus $70.4 \%, P>0.05)$ or litter size $(1.9 \pm 0.1$ lambs per ewe versus $1.8 \pm 0.1$ lambs per ewe, $P>0.05)$ in ewes mated with immunized or control rams.

\section{Serum FSH concentrations}

Mean FSH concentrations in June (days 358-360) and August (day 407) were significantly higher in immunized compared with control rams (Table 2) and were correlated with antibody titres $\left(r^{2}=0.32, P<0.05\right.$ for June; $r^{2}=0.77$, $P<0.001$ for August) and scrotal circumference $\left(r^{2}=0.36\right.$, $P<0.05)$. Pulses of FSH were not detected in either treatment group (e.g. see Fig. 3); neither was there any consistent pattern of change in FSH concentrations in rams over the $60 \mathrm{~h}$ blood sampling period (days 358-360).

\section{Serum LH concentrations}

There was no effect $(P>0.05)$ of inhibin immunization on mean or basal LH concentrations or LH pulse frequency (Table 2). However, the mean amplitude of $\mathrm{LH}$ pulses was higher in immunized rams compared with controls, and this was correlated with antibody titre $\left(r^{2}=0.64, P<0.01\right)$.

\section{Serum testosterone concentrations}

Testosterone pulses were observed in all rams in response to an LH pulse. There was no effect $(P>0.05)$ of bINH immunization on mean or basal testosterone concentrations or on testosterone pulse amplitude (Table 2), and none was correlated to antibody titre $(P>0.05)$.

\section{$G n R H$-induced $F S H$ and $L H$ release}

GnRH-induced FSH release (area under response curve above basal concentrations obtained from samples taken during the $12 \mathrm{~h}$ period before GnRH injection) was higher $(643.2 \pm 130.9$ versus $257.3 \pm 40.2$ arbitrary area units, $P<0.05)$ in immunized rams compared with controls and this was correlated to antibody titres $\left(r^{2}=0.67, P<0.005\right)$. However, when expressed as a percentage of the mean 
Table 2. Effect of immunization of adult rams against bovine inhibin $\alpha 1-26-\mathrm{Gly}-\mathrm{Tyr}$ on mean FSH concentrations sampled every $3 \mathrm{~h}$ for $12 \mathrm{~h}$ on three consecutive days in June (days 358-360), on FSH and $\mathrm{LH}$ concentrations measured in a subgroup every $12 \mathrm{~min}$ for $12 \mathrm{~h}$ in August (day 407), and on testosterone concentrations subsequently measured in the same sera every $12 \mathrm{~min}$ for a specific $2-4 \mathrm{~h}$ period selected to span two LH pulses in each ram; values are means ( \pm SEM)

\begin{tabular}{|c|c|c|c|}
\hline & $n$ & Control & Immunized \\
\hline Mean FSH concentration (ng ml ${ }^{-1}$ ) (June) & 15 & $2.99 \pm 0.34^{\mathrm{a}}$ & $5.81 \pm 0.72^{c}$ \\
\hline Mean FSH concentration (ng ml ${ }^{-1}$ ) (August) & 5 & $2.01 \pm 0.30^{\mathrm{a}}$ & $4.81 \pm 0.92^{\mathrm{b}}$ \\
\hline Mean LH concentration $\left(\mathrm{ng} \mathrm{ml}^{-1}\right)$ & 5 & $1.01 \pm 0.26^{\circ}$ & $1.35 \pm 0.27^{\mathrm{a}}$ \\
\hline Basal $\mathrm{LH}$ concentration $\left(\mathrm{ng} \mathrm{ml}{ }^{-1}\right.$ ) & 5 & $0.83 \pm 0.21^{\mathrm{a}}$ & $0.94 \pm 0.23^{\mathrm{a}}$ \\
\hline LH pulse amplitude (ng $\mathrm{ml}^{-1}$ ) & 5 & $0.76 \pm 0.20^{\mathrm{a}}$ & $1.59 \pm 0.23^{b}$ \\
\hline LH pulse frequency (pulses $h^{-1}$ ) & 5 & $0.49 \pm 0.05^{\mathrm{a}}$ & $0.45 \pm 0.07^{\mathrm{a}}$ \\
\hline Mean testosterone concentration (ng $\mathrm{ml}^{-1}$ ) & 5 & $4.32 \pm 0.44^{\mathrm{a}}$ & $3.95 \pm 0.50^{\mathrm{a}}$ \\
\hline Basal testosterone concentration (ng ml ${ }^{-1}$ ) & 5 & $3.23 \pm 0.59^{\mathrm{a}}$ & $2.87 \pm 0.24^{\mathrm{a}}$ \\
\hline Testosterone pulse amplitude (ng $\mathrm{ml}^{-\mathrm{I}}$ ) & 5 & $6.43 \pm 0.97^{\mathrm{a}}$ & $5.43 \pm 1.29^{\mathrm{a}}$ \\
\hline
\end{tabular}

Values in a row with different superscripts are significantly different: ${ }^{a b} p<0.02 ;{ }^{a . c} p<0.001$

Ram 6 Control
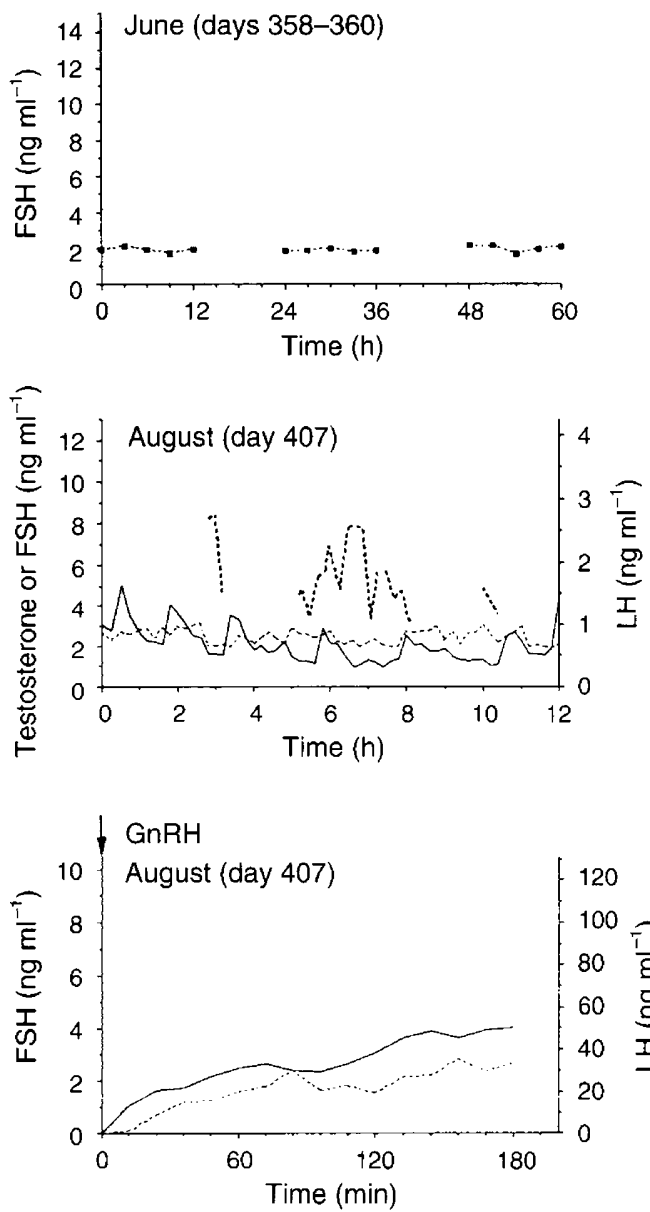

Ram 17 Immunized
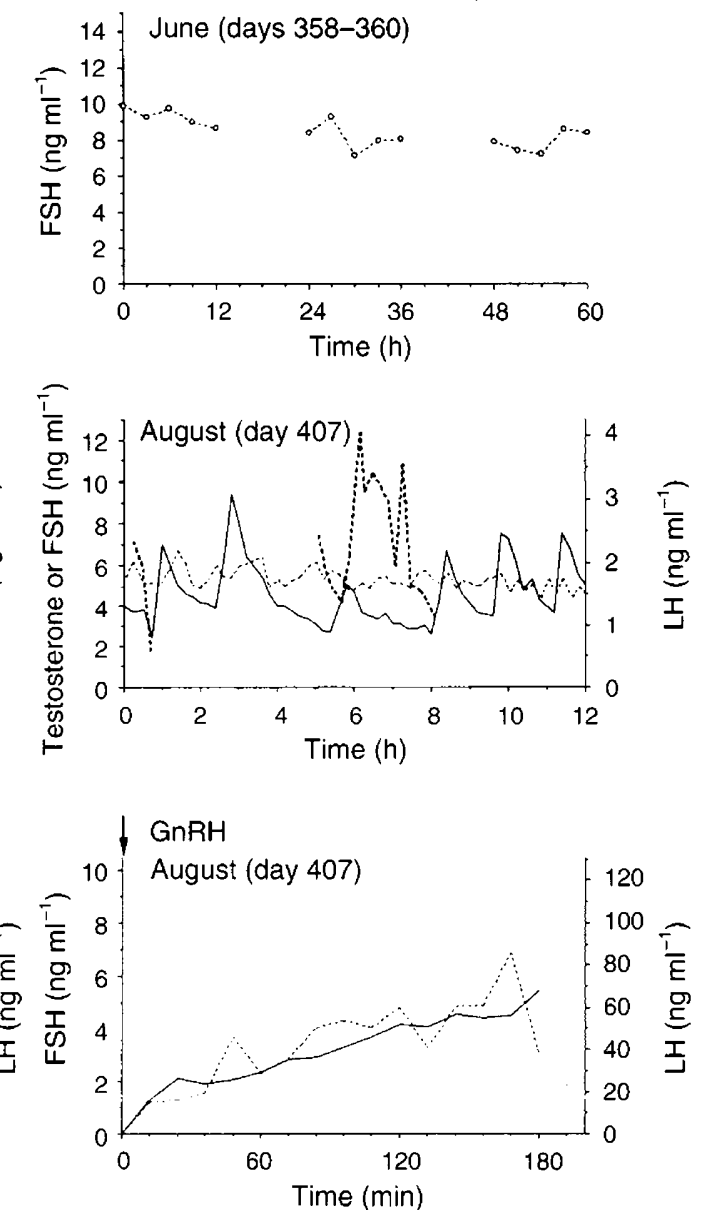

Fig. 3. Serum FSH $(-\cdots), \mathrm{LH}(-)$ and testosterone $(\cdots \cdot)$ concentrations, and GnRH-induced FSH and LH release in a representative immunized and control ram. Blood samples were collected on days $358-360$ at $3 \mathrm{~h}$ intervals for $12 \mathrm{~h}$, and on day 407 at $12 \mathrm{~min}$ intervals for $12 \mathrm{~h}$ before, and for $3 \mathrm{~h}$ after, GnRH administration.

FSH concentration before the GnRH challenge, there was no difference between groups $(P>0.05)$, nor was this correlated with antibody titre $(P>0.05)$. GnRH-induced
LH release was unaltered by immunization against bINH $(6304.3 \pm 1184.8$ versus $5464.2 \pm 1110.4$ arbitrary area units, $P>0.05)$. 


\section{Discussion}

This study demonstrates that active immunization of adult rams against the synthetic $\alpha I-26-G l y-T y r$ bovine inhibin peptide conjugated to HSA raised inhibin antibody titres, increased FSH concentrations, LH pulse amplitude and scrotal circumference, without measurable effects on semen characteristics or ram fertility following natural service of synchronized ewes. After immunization, antibodies that bound the ${ }^{125} \mathrm{I}$ labelled $\alpha$ I-26-Gly-Tyr peptide were present in the serum of immunized rams, but were not detected in control rams. The antibody titre response was approximately similar in magnitude and duration to that observed in other studies using the same inhibin fragment in ewes (Boland et al., 1994) and heifers (Scanlon et al., 1993). However, it is not clear why such a wide range in antibody titres was observed between individual animals. This might be due to variations in the immune status or the sensitivity of the immune system to an extrinsic antigen between individual animals (Simpson, 1984).

The epididymal sperm reserves of rams were depleted using a frequent semen collection procedure, to examine thoroughly the effects of inhibin immunization on sperm production. The lack of an effect of bINH immunization on any of the semen characteristics examined, despite an increase in both the concentration of FSH and scrotal circumference, was surprising, since it has been demonstrated that FSH (Walton et al., 1978; Waites et al., 1983; Schanbacher, 1988) and scrotal circumference (Willett and Ohms, 1957; Foote, 1978; Coulter, 1980; Cameron et al., 1984a, b) are key determinants of spermatogenic rate. Furthermore, it has been demonstrated that the rate of spermatogenesis can be reduced by administering bioactive inhibins to rodents (van Dissel-Emiliani et al., 1989; Hakovitra et al., 1993) or by immunizing rams against FSH (Kilgour et al., 1993). The fact that scrotal circumferences were positively correlated with mean FSH concentrations, which were, in turn, highly correlated to antibody titres, strongly suggests that immunoneutralization of endogenous inhibins results in higher circulating FSH concentrations and thus increases testicular growth. This suggestion is supported, at least in part, by results indicating that FSH is a principal factor regulating testicular size (Lincoln and McNeilly, 1989; Lincoln et al, 1990) and by the increase in testicular diameter reported in ram lambs actively immunized against inhibin-enriched preparations from bovine follicular fluid (Al-Obaidi et al., 1987).

There is conflicting evidence from studies in vivo and in vitro with respect to the putative role of inhibins as selective regulators of $\mathrm{FSH}$ secretion, without effect on LH. It is clear from this study that active immunization of adult rams against bINH increases the peripheral concentrations of FSH twofold in June and August. In addition, there was a significant correlation, within immunized rams, between FSH concentrations and inhibin antibody titres. It is interesting to note that the difference in FSH concentrations between immunized and control rams in this study is similar in magnitude to that reported between castrated and intact rams (Tilbrook et al., 1993a), suggesting that inhibin is a potent systemic inhibitor of $\mathrm{FSH}$ in rams. FSH pulses were not detected during either sampling period, supporting previous reports that $\mathrm{FSH}$ is non-pulsatile in rams (Fraser and Lincoln, 1980; Tilbrook et al., 1993b). Mean serum FSH concentrations were approximately
$1 \mathrm{ng} \mathrm{ml}{ }^{-1}$ higher in both immunized and control rams during June than in August. It is likely that the higher FSH concentration in June represents a temporary seasonal increase during the developing phase of the testes (Lincoln et al., 1990).

Mean and basal LH concentrations and LH pulse frequency (August) were not different between immunized and control rams. This observation supports the contention that inhibins are selective regulators of FSH and have little or no effect on LH. In support of this finding, previous studies have reported that mean and basal LH concentrations are unaltered by immunization against inhibins in rams (Al-Obaidi et al., 1987), bulls (Schanbacher, 1991), ewes (Wrathall et al., 1992) and heifers (Scanlon et al., 1993). Furthermore, infusion of rams with human recombinant inhibin $\mathrm{A}$ does not alter $\mathrm{LH}$ concentrations (Tilbrook et al., 1993a) and basal LH secretion from ovine pituitary cell cultures is not influenced by bovine follicular fluid (Huang and Miller, 1984; Muttukrishna and Knight, 1990) or highly purified bovine inhibin (Muttukrishna and Knight, 1990). However, Voglmayr et al. (1990) demonstrated that immunization of rams against a human recombinant inhibin $\alpha$ subunit increases mean $\mathrm{LH}$ concentrations, while in bulls mean $\mathrm{LH}$ concentrations are reduced following immunization against bovine inhibin a1-26 (Martin et al., 1991) - although alterations in testosterone concentrations may explain these discrepancies.

Immunization against inhibin a1-26-Gly-Tyr increased LH pulse amplitude twofold in immunized rams compared with controls, and pulse amplitude was significantly correlated with antibody titre. This result was unexpected and contradictory to results from castrated rams (Tilbrook et al., 1993a) and ovariectomized ewes (Findlay et al., 1987). Inhibins have been shown to exert a paracrine effect on LH-stimulated testosterone release in the testes (Hsueh et al., 1987); however, immunization in this study did not significantly affect basal, mean testosterone concentrations or testosterone pulse amplitude. Interestingly, the relationship between $\mathrm{LH}$ pulse amplitude and the mean testosterone concentrations was altered by bINH immunization; the biological significance of this finding is unclear.

GnRH-induced FSH release was significantly higher in bINH-immunized rams than in controls and was correlated with antibody titres. GnRH-induced $\mathrm{LH}$ release was unaltered by immunization. These data are consistent with results from inhibin immunization of ewes (Findlay et al., 1989), heifers (Scanlon et al., 1993) and bulls (Schanbacher, 1991), but contradict studies in vitro in which inhibin enhanced GnRHstimulated LH release from ovine pituitary cells (Huang and Milier, 1984; Muttukrishna and Knight, 1990).

The results in this study might be explained by the hypothesis that an upper limit of spermatogenic rate is set by the number of Sertoli cells (determined during the prepubertal period) and that each Sertoli cell can only support a certain number of developing germ cells, adequate gonadotrophin support thus being necessary to approach maximal spermatogenic efficiency (Culler and Negro-Vilar, 1988). This seems to be true for rats (Orth et al., 1988) and, recently, the administration of FSH has been shown to increase the mitotic rate of Sertoli cells, seminiferous tubule length and the relative mass of spermatocytes and spermatids in prepubertal boars (Swanlund et al., 1995). In support of these studies, manipulation of the 
FSH-inhibin endocrine axis by immunization against inhibins early in life has been reported to increase sperm output in the urine of rams (Al-Obaidi et al., 1987) and testicular sperm density of bulls (Martin et al., 1991; Schanbacher, 1991), but to have no significant effect on epididymal sperm reserves when rams were immunized as adults (Voglmayr et al., 1990). However, this hypothesis does not explain why bINH immunization does not affect sperm output during the non-breeding season when the spermatogenic rate is submaximal. An alternative explanation is that inhibins inhibit spermatogonial development in a paracrine manner (van Dissel-Emiliani et al., 1989; Hakovitra et al., 1993), and that the antibodies raised by bINH immunization are excluded from the adluminal compartment of the seminiferous tubules by the blood-testis barrier, as suggested by Schanbacher (1991). The relative importance of paracrine and endocrine actions of inhibins and the precise functional roles of inhibins and FSH in the regulation of spermatogenesis and testicular function need to be determined.

In summary, active immunization of adult rams against bovine inhibin $\alpha 1-26-G l y-T y r$ conjugated to HSA resulted in antibody titres, but did not alter semen volume or the concentration, output, quality or fertility of spermatozoa; however, scrotal circumference, serum FSH concentrations and GnRH-induced FSH release were increased. FSH is nonpulsatile in the adult ram; immunization against inhibin increased LH pulse amplitude but did not affect mean or basal $\mathrm{LH}$ concentrations, $\mathrm{LH}$ pulse frequency or $\mathrm{GnRH}$-induced LH release.

The authors thank the staff at Lyons Research Farm for technical expertise, G. Claffey, N. Hynes, S. McDonnell and S. NiCeallaigh for laboratory assistance, D. Williams for help with statistical analyses, and M. Kane (University College, Galway) for peptide synthesis and conjugation. The authors thank G. Niswender, Colorado State University, for providing testosterone antiserum and $\mathrm{N}$. Corrigan for typing the manuscript. Abstracts of these data were presented at the Annual Conference of the Society for the Study of Fertility in 1995 and the 13th International Congress on Animal Reproduction in 1996.

\section{References}

Al-Obaidi SAR, Bindon BM, Hillard MA and O'Shea T (1987) Reproductive characteristics of lambs actively immunized early in life with inhibin-enriched preparations from follicular fluid of cows Journal of Reproduction and Fertility $81403-414$

$\mathrm{Au}$ CL, Robertson DM and de Kretser DM (1984) An in vivo method for estimating inhibin production by adult rat testes journal of Reproduction and Fertility $71259-265$

Awonyi CA, Sprando RL, Santulli R, Chandrashekar V, Ewing LL and Zirkin BR (1990) Restoration of spermatogenesis by exogenously administered testosterone in rats made azoospermic by hypophysectomy or withdrawal of luteinizing hormone alone Endocrinology 127 177-184

Barlett JMS, Weinbauer GF and Nieschlag E (1989) Differential effects of FSH and testosterone on the maintenance of spermatogenesis in the adult hypophysectomized rat Journal of Endocrinology 121 49-58

Bicsak T, Vale W, Vaughan J, Tucker E, Cappel S and Hsueh AJW (1987) Hormonal regulation of inhibin production by cultured Sertoli cells Molecular and Cellular Endocrinology $49211-217$

Boccabella AV (1963) Reinitiation and restoration of spermatogenesis with testosterone propionate and other hormones after a long term posthypophysectomy regression Endocrinology 72 787-798

Boland MP, Sunderland SJ, Williams DH, Kane M, Headon DR and Roche JF (1994) Effect of immunization of ewes against $\alpha 1-26$ inhibin fragment on antibody titre, ovulation and lambing rate Animal Reproduction Science 34 24I-25I.

Burger HG and Igarashi M (1988) Inhibin: definition and nomenclature, including related substances Endocrinology 122 1701-1702

Cameron AWN, Fairnie IJ, Curnow EJ and Lindsay DR (1984a) The output of spermatozoa of naturally mated rams Tenth International Congress of Animal Reproduction and Artificial Insemination, Urbana-Champaign, IL 2266

Cameron AWN, Fairnie IJ, Curnow EJ, Keogh EJ and Lindsay DR (1984b) The effect of frequency of semen collection and testicular size on the output of spermatozoa by rams Tenth International Congress of Animal Reproduction and Artificial Insemination, Urbana-Champaign, IL 2267

Coulter GH (1980) Testicular development: its management and significance in young beef bulls Proceedings of the Eighth Technical Conference, National Association of Animal Breeders, Columbia p 106

Courot M, Hochereau-de Reviers MT, Monet-Kuntz C, Locatelli A, Pisselet C, Blanc MR and Dacheux JL (1979) Endocrinology of spermatogenesis in the hypophysectomized ram Journal of Reproduction and Fertility Supplement 26 165-173

Crowe MA, Padmanabhan V, Hynes N, Sunderland SJ, Beitins IZ and Enright WJ (1995) Validation of a sensitive RIA for measurement of serum FSH in cattle, and its correlation with FSH bioassay Journal of Reproduction and Fertility Abstract Series 15 Abstract 112

Culler MD and Negro-Vilar A (1988) Passive immunoneutralization of endogenous inhibin: sex-related differences in the role of inhibin during development Molecular and Cellular Endocrinology 58 263-273

de Kretser DM and Robertson DM (1989) The isolation and physiology of inhibin and related proteins Biology of Reproduction $4033-47$

Evans G and Maxwell WMC (1987) Handling and examination of semen. In Salamon's Artificial Insemination of Sheep and Goats pp 93-106 Eds G Evans and WMC Maxwell. Butterworths, London

Findlay JK, Robertson DM and Clarke IJ (1987) Influence of dose and route of administration of bovine follicular fluid and the suppressive effect of purified bovine inhibin (Mr 31 000) on plasma FSH concentrations in ovariectomized ewes Journal of Reproduction and Fertility 80 455-461

Findlay JK, Doughton BW, Robertson DM and Forage RG (1989) Effects of immunization against recombinant bovine inhibin $\alpha$ subunit on circulating concentrations of gonadotrophins in ewes Joumal of Endocrinology 120 $59-65$

Foote RH (1978) Factors influencing the quantity and quality of semen harvested from bulls, rams, boars and stallions Journal of Animal Science Supplement 47 1-11

Fraser HM and Lincoln GA (1980) Effects of chronic treatment with a LHRH agonist on the secretion of LH, FSH and testosterone in the ram Biology of Reproduction 22 269-276

Gonzales GF, Risbridger GP and de Kretser DM (1988) In vitro synthesis and release of inhibin in response to $\mathrm{FSH}$ stimulation by isolated segments of seminiferous tubules from normal adult male rats Molecular and Cellular Endocrinology 59 179-185

Hakovitra H, Kaipia A, Soder O and Parvinen M (1993) Effects of activin-A, inhibin- $A$, and transforming growth factor- $\beta 1$ on stage-specific deoxyribonucleic acid synthesis during rat seminiferous epithelial cycle Endocrinology $133 \quad 1664-1668$

Hancock JL (1951) A staining technique for the study of temperature-shock in semen Nature $167323-324$

Hsueh AJW, Dahl KD, Vaughan J, Tuker E, Rivier J, Bardin CW and Vale WW (1987) Heterodimers and homodimers of inhibin subunits have different paracrine action in the modulation of luteinizing hormone-stimulated androgen biosynthesis Proceedings of the National Academy of Sciences USA 84 5082-5086

Huang ESR and Miller WL (1984) Porcine ovarian inhibin preparations sensitize cultured ovine gonadotrophs to luteinizing hormone-releasing hormone Endocrinology 115 513-519

Kilgour RJ, Courot M, Pisselet C, Dubois MP and Sairam MR (1993) Inhibition of FSH affects spermatogenesis in the mature ram Animal Reproduction Science 32 213-225

Le Gac F and de Kretser DM (1982) Inhibin production by Sertoli cell cultures Molecular and Cellular Endocrinology 28 487-498

Lincoln GA and McNeilly AS (1989) Inhibin concentrations in the peripheral blood of rams during a cycle of testicular activity induced by changes in photoperiod or treatment with melatonin Journal of Endocrinology $\mathbf{1 2 0}$ R9-R13

Downloaded from Bioscientifica.com at 04/26/2023 $08: 46: 41 \mathrm{AM}$ via free access 
Lincoln GA, Lincoln CE and McNeilly AS (1990) Seasonal cycles in the blood plasma concentrations of FSH, inhibin and testosterone, and testicular size in rams of wild, feral and domesticated breeds of sheep Journal of Reproduction and Fertility 88 623-633

Martin TL, Williams GL, Lunstra DD and Ireland JJ (1991) Immunoneutralization of inhibin modifies hormone secretion and sperm production in bulls Biology of Reproduction 45 73-77

Matteri RL, Roser JF, Baldwin DM, Lipovetsky V and Papkoff H (1987) Characterization of a monoclonal antibody which detects luteinizing hormone from diverse mammalian species Domestic Animal Endocrinology 4 157-165

Merriam GR and Wachter KW (1982) Algorithms for the study of episodic hormone secretion American Journal of Physiology 243 E3IO-E318

Morris DG, McDermott MG, Diskin MG, Morrison CA, Swift PG and Sreenan JM (1993) Effect of immunization against synthetic peptide sequences of bovine inhibin $\alpha$-subunit on ovulation rate and twin calving rate in heifers Journal of Reproduction and Fertility 97 255-261

Muttukrishna S and Knight PG (1990) Effects of crude and highly purified bovine inhibin ( $\mathrm{Mr} 32000$ form) on gonadotrophin production by ovine pituitary cells in vitro: inhibin enhances gonadotrophin-releasing hormoneinduced release of LH Journal of Endocrinology 127 149-159

Orth JM, Glen LG and Albert AL (1988) Evidence from cell-depleted rats indicates that spermatid number in adults depends on numbers of Sertoli cells produced during perinatal development Endocrinology 122 787-794

Reichlin M (1980) Use of glutaraldehyde as a coupling agent for proteins and peptides. In Methods in Enzymology (Vol. 70), pp 159-165 Eds HV Vunakis and JJ Langone. Academic Press, New York

Rivier C and Vale W (1989) Immunoneutralization of endogenous inhibin modifies hormone secretion and ovulation rate in the rat Endocrinology $\mathbf{1 2 5}$ 152-157

Ronayne E, Enright WJ and Roche JF (1993) Effects of continuous administration of gonadotropin-releasing hormone $(\mathrm{GnRH})$ or a potent $\mathrm{GnRH}$ analogue on blood luteinizing hormone and testosterone concentrations in prepubertal bulls Domestic Animal Endocrinology 10 179-189

Russell AJF, Doney JM and Gunn RG (1969) Subjective assessment of body fat in live sheep Journal of Agricultural Science 72 451-454

Scanlon AR, Sunderland SJ, Martin TL, Goulding D, O'Callaghan D, Williams DH, Headon DR, Boland MP, Ireland JJ and Roche JF (1993) Active immunization of heifers against a synthetic fragment of bovine inhibin Journal of Reproduction and Fertility $97213-222$

Schanbacher BD (1988) Radioimmunoassay of inhibin: serum responses to unilateral and bilateral orchidectomy Endocrinology 123 2323-2330

Schanbacher BD (1991) Pituitary and testicular responses of beef bulls to active immunization against inhibin alpha Journal of Animal Science 69 252-257

Schanbacher BD and D'Occhio M\} (1982) Validation of a direct radioimmunoassay for testosterone in unextracted serum from five species: application to the study of the hypothalamic-pituitary-gonadal axis in males Journal of Andrology 3 45-51

Simpson E (1984) The cellular basis of the immune response. In Immunological Aspects of Reproduction in Mammals pp 1-11 Ed. DB Crighton. Butterworths, London
Swanlund DJ, N'Diaye MR, Loseth KJ, Pryor JL and Crabo BG (1995) Diverse testicular responses to exogenous growth hormone and follicle-stimulating hormone in prepubertal bulls Biology of Reproduction 53 749-757

Sweeney T (1995) Photoperiodic Regulation of Seasonality in the Ewe PhD Thesis, National University of Ireland, Dublin

Tilbrook AJ, de Kretser DM and Clarke IJ (1992) A role for inhibin in the regulation of the secretion of follicle-stimulating hormone in male domestic species Domestic Animal Endocrinology 9 243-260

Tilbrook AJ, de Kretser DM and Clarke IJ (1993a) Human recombinant inhibin A suppresses follicle-stimulating hormone to intact levels but has no effect on luteinizing hormone in castrated rams Biology of Reproduction 49 779788

Tilbrook AJ, de Kretser DM and Clarke IJ (1993b) Human recombinant inhibin $\mathrm{A}$ and testosterone act directly at the pituitary to suppress plasma concentrations of FSH in castrated rams Journal of Endocrinology 138 $181-189$

Ultee van-Gessel AM, Leemborg FG, de Jong FH and van der Molen HJ (1986) In vitro secretion of inhibin-like activity by Sertoli cells from normal and prenatally irradiated immature rats Journal of Endocrinology 109 411-418

van Dijk S, Steenbergen J, Gielen JT and de Jong FH (1986) Sexual dimorphism in immunoneutralization of bioactivity of rat and ovine inhibin Journal of Endocrinology 111 255-261

van Dissel-Emiliani FMF, Grootenhuis AJ, de Jong FH and de Rooij DG (1989) Inhibin reduces spermatogonial numbers in testes of adult mice and Chinese hamsters Endocrinology 125 1898-1903

Verhoeven $G$ and Franchimont $P$ (1983) Regulation of inhibin secretion by Sertoli cell-enriched cultures Acta Endocrinologica 102 136-143

VogImayr JK, Mizumachi M, Washington DW, Chen C-LC and Bardin CW (1990) Immunization of rams against human recombinant inhibin $\alpha$-subunit delays, augments, and extends season-related increase in blood gonadotrophin levels Biology of Reproduction 42 81-86

Waites GMH, Wenstrom JC, Crabo BG and Hamilton DW (1983) Rapid compensatory hypertrophy of the testis after neonatal hemiorchidectomy: endocrine and light microscopical morphometric analyses Endocrinology 112 21592167

Walton JS, Ewins JD and Waites GMH (1978) Feedback control of folliclestimulating hormone in pre- and postpubertal rams as revealed by hemicastration Journal of Endocrinology 77 75-84

Willett EL and Ohms JI (1957) Measurement of testicular size and its relation to production of spermatazoa by bulls Journal of Dairy Science 40 15591569

Wrathall JHM, McLeod BJ, Glencross RG, Beard AJ and Knight PG (1990) Inhibin immunoneutralization by antibodies raised against synthetic peptide sequences of inhibin $\alpha$-subunit: effects of gonadotrophin concentrations and ovulation rate in sheep Journal of Endocrinology 124 167-176

Wrathall JHM, McLeod BJ, Glencross RG and Knight PG (1992) Effects of active immunization against a synthetic peptide sequence of the inhibin $\alpha$-subunit on plasma gonadotrophin concentrations, ovulation rate and lambing rate in ewes Journal of Reproduction and Fertility 95 175-182 